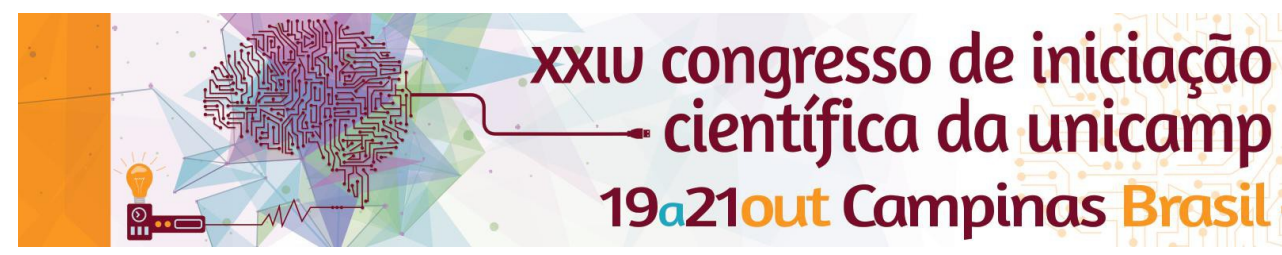

\title{
Comportamento alimentar, condições orais e desenvolvimento da oclusão decídua em crianças na primeira infância
}

\section{Emanuella Meira Paschoaleto*, Maria Beatriz Duarte Gavião.}

\section{Resumo}

Este projeto tem por objetivo verificar o comportamento na amamentação pela aplicação da versão em português do Baby Eating Behaviour Questionnaire (BEBQ) e a associação com os aspectos nutricionais. Além disso, será verificada a dieta das crianças e as possíveis influências no desenvolvimento da oclusão decídua e das condições orais.

Palavras-chave:

Nutrição, oclusão, dentição decídua..

\section{Introdução}

Mastigar é uma função de aprendizagem que se aprimora durante o cresci foram examinadas 17 crianças na faixa etária de 6 a 36 meses. O BEBQ foi fornecido às mães e autoaplicado mento e desenvolvimento. A dificuldade na mastigação, devido à má saúde bucal, é provavelmente o fator que pode influenciar a alimentação. $\mathrm{O}$ desenvolvimento psicossocial e bem-estar podem ser afetados em crianças com problemas nutricionais. Portanto, é importante que seja verificado o comportamento na amamentação, aspectos nutricionais e associar com os hábitos e condições orais.

\section{Resultados e Discussão}

Foram examinadas 17 crianças na faixa etária de 6 a 36 meses. Realizou-se a anamnese para obtenção dos dados das crianças, exame clínico bucal e dentário e avaliação da saúde bucal.

Tabela 1. Dados descritivos das crianças examinadas

\begin{tabular}{|l|l|}
\hline Meninas & $\mathrm{n}=5$ \\
\hline Meninos & $\mathrm{n}=12$ \\
\hline Idade (meses) & $27,12 \pm 5,8$ \\
& 2 \\
\hline Peso ao nascer $(\mathrm{kg})$ & $3,37 \pm 0,56$ \\
\hline Altura ao nascer $(\mathrm{cm})$ & $48,53 \pm 2,0$ \\
& 3 \\
\hline Peso atual $(\mathrm{Kg})$ & $13,60 \pm 3,1$ \\
& 3 \\
\hline Altura atual $(\mathrm{cm})$ & $89,40 \pm 6,9$ \\
& 7 \\
\hline Oclusão normal & $\mathrm{n}=8$ \\
\hline Mordida aberta & $\mathrm{n}=6$ \\
\hline Mordida Cruzada & $\mathrm{n}=2$ \\
\hline
\end{tabular}

O BEBQ foi fornecido às 17 mães e autoaplicado. A cada questão do questionário foi acrescentada a alternativa "não entendi", com a finalidade de identificar questões que não fossem compreendidas. A alternativa "não entendi" foi assinalada por três mães em 4 questões, não atingindo assim $85 \%$ de respostas não compreendidas que indicariam revisão das questões.
Tabela 2. Escores (mediana) das questões do BEBQ

\begin{tabular}{|c|c|}
\hline 1. Meu bebê parece satisfeito enquanto toma leite. & 5 \\
\hline $\begin{array}{l}\text { Meu bebê frequentemente quer mais leite do } \\
\text { que eu ofereço. }\end{array}$ & 2,5 \\
\hline 3. Meu bebê adora tomar leite. & 5 \\
\hline 4. Meu bebê tem bastante apetite. & 5 \\
\hline $\begin{array}{l}\text { 5. Meu bebê termina de tomar leite } \\
\text { rapidamente. }\end{array}$ & 3 \\
\hline $\begin{array}{l}\text { 6. Meu bebê fica angustiado enquanto toma } \\
\text { leite. }\end{array}$ & 1 \\
\hline 7. Meu bebê fica saciado (cheio) facilmente. & 3 \\
\hline $\begin{array}{l}\text { 8. Se Ihe fosse permitido, meu bebê tomaria } \\
\text { leite demais. }\end{array}$ & 2 \\
\hline $\begin{array}{l}\text { 9. Meu bebê leva mais de } 30 \text { minutos para } \\
\text { terminar de mamar. }\end{array}$ & 2 \\
\hline $\begin{array}{l}\text { 10. Meu bebê fica satisfeito antes de tomar todo } \\
\text { o leite que eu acho que ele(a) deveria tomar. }\end{array}$ & 2 \\
\hline 11. Meu bebê mama devagar. & 3 \\
\hline $\begin{array}{l}\text { 12. Mesmo quando meu bebê acabou de mamar } \\
\text { bem ele(a) fica feliz de tomar leite novamente se } \\
\text { for oferecido. }\end{array}$ & 1,5 \\
\hline $\begin{array}{l}\text { 13. Meu bebê tem dificuldade em realizar uma } \\
\text { refeição completa }\end{array}$ & 1 \\
\hline $\begin{array}{l}\text { 14. Meu bebê está sempre exigindo ser } \\
\text { alimentado. }\end{array}$ & 2 \\
\hline $\begin{array}{l}\text { 15. Meu bebê suga cada vez mais devagar ao } \\
\text { longo de uma refeição. }\end{array}$ & 2 \\
\hline $\begin{array}{l}\text { 16. Se Ihe fosse dada a oportunidade, meu bebê } \\
\text { estaria sempre tomando leite. }\end{array}$ & 2 \\
\hline 17. Meu bebê gosta da hora de mamar. & 5 \\
\hline $\begin{array}{l}\text { 18. Meu bebê pode facilmente tomar leite } 30 \\
\text { minutos após a última mamada. }\end{array}$ & 2,5 \\
\hline
\end{tabular}

\section{Conclusão}

$A$ versão do $B E B Q$ é viável para aplicação na continuidade da amostra do projeto de pesquisa.

\section{Agradecimentos}

Agradeço ao CNPQ pela bolsa de estudos e a orientação da Profa. Dra. Mariz Beatriz Duarte Gavião 